\title{
MR. JUSTICE FRANKFURTER: JUDGMENT AND THE FOURTEENTH AMENDMENT
}

\author{
LOUIS H. POLLAKं \\ "The gleaming bayonets are ugly, and the cause for \\ their presence is enough to grieve the heart of a nation. \\ But they carry a proud and beautiful message. They \\ say what too long was unsaid before, that ours is a \\ goverment of law, that the Constitution is the su- \\ preme law of the land, that the Supreme Court is the \\ final interpreter of the Constitution, that edicts of the \\ Court are not to be flouted."
}

-Civil Liberties, Oct. 1957, p. 1 , col. 3 , quoting editorial in Louisville Courier-Journal.

SECond in importance only to what the Supreme Court decided in the School Cases was the fact that the Court spoke unanimously. ${ }^{1}$ So often and so sharply divided on lesser issues, the Justices spoke as one on the greatest issue any of them had met or was likely ever to meet. ${ }^{2}$ It is certain that the Justices are also unanimous today in their concern that Little Rock be remembered as the beginning rather than the end of effective compliance with their mandate.

One may hazard the guess that of all the robed brethren the man most profoundly troubled by present challenges to the integrity of the Court's processes is Mr. Justice Frankfurter. The Justice has devoted the better part of a long and thoughtful career to shaping the Court's proper role in the resolution of those "conundrums of government ... [which] must be solved within the recondite legal arrangements of our federalism."3 In Frankfurter's pantheon are "judges who were alert in safeguarding and promoting the interests of liberty and human dignity through law." 4 But the same judges were also "mindful of the relation of our federal system to a progressively democratic

$\dagger$ Associate Professor of Law, Yale Law School.

The writer wishes to acknowledge the substantial assistance of William Kass and Michael Pertschuk, second year students at the Law School.

1. Brown v. Board of Educ., 347 U.S. 483 (1954), 349 U.S. 294 (1955) ; cf. Bolling v. Sharpe, 347 U.S. 497 (1954).

2. Plessy v. Ferguson, 163 U.S. 537 (1896), was not, of course, unanimous; Justice Harlan's historic dissent-notwithstanding his own failure to pursue it in later cases, see Frankfurter, John Marshall and the Judicial Function, 69 HARv. L. REv. 217, 230 (1955), reprinted in FRANKFURTER, OF LAW AND MEN 3, 19-20 (1956)-was in a very important sense the seed of Plessy's ultimate demise. See Cahn, Jurisprudence, 30 N.Y.U.L. REv. $150,168-69$ (1955).

3. Frankfurter, Mr. Justice Holmies and the Supreme Court 67 (1938).

4. Adamson v. California, 332 U.S. 46, 62 (1947) (concurring opinion). 
society and therefore duly regardful of the scope of authority that was left to the States even after the Civil War."5

In seeking the right balance, Frankfurter may in many cases seem too insistent on giving "the freest possible scope to States,"B overly zealous in his "alert deference to the judgment of the state court under review," too ready, without reaching the merits, to find the issue either "political"s or otherwise nonjusticiable," or too quick to uncover the "fatal weakness ... that the question of a denial of one or more putative federal rights is nowhere properly raised on the record before us." 10 His relentless vocabulary of self-effacement is not without its critics-those who regard Frankfurter's "judicial self-denial" as camouflage: "the same old conservatism, poured into new containers . . .."11 This appraisal, however, "is unacceptable to those who take the more modest view that the Court's chief concern is justice under law. For them, the great judge is the humilitarian, the respecter of those 'technicalities' which allocate among many agencies different responsibilities in the pursuit of Justice."12

Whichever view is taken, slogans of judicial reticence are unlikely to rouse men's hearts and point to new horizons. Frankfurter's words have brought few to the barricades. Nevertheless, the opinions reflecting Frankfurter's strict adherence to patterns of restraint lend impressive added weight to those other opinions written or concurred in by Frankfurter-opinions like those in the School Cases-which test state action on its merits and find it incompatible with freedoms contained in the Fourteenth Amendment.

\section{Escape From Judgment}

Back in the days of innocence, there was plenty of time for critics of the Supreme Court's work to stick pins in dolls and call it scholarship. More recently, however, there has been wider recognition that the "attitudes of the Justices are a problem in national policy, and the study of the Court's work is not advanced by the pressure of factionalism."'13 The cult of personality

\section{Ibid.}

6. Haley v. Ohio, 332 U.S. 596, 604 (1948) (concurring opinion).

7. Malinski v. New York, 324 U.S. 401,417 (1945) (concurring opinion) ; Adamson v. California, 332 U.S. 46, 68 (1947) (concurring opinion).

8. E.g., Colegrove v. Green, 328 U.S. 549,552 (1946).

9. See Coleman v. MIiller, 307 U.S. 433, 460 (1939) (separate opinion). Generally, the issue is deemed not justiciable because "to the expert feel of lawyers," it is not cut from the stuff of "case or controversy." Joint Anti-Fascist Refugee Comm. v. McGrath, 341 U.S. 123, 150 (1951) (concurring opinion). Sometimes an undoubted "case" is thought to be one in which equity should stay its hand. E.g., Stefanelli v. Minard, 342 U.S. 117 (1951).

10. Jennings v. Illinois, 342 U.S. 104, 115 (1951) (dissenting opinion).

11. Rodell, Book Review, 56 YaLE L.J. 1462, 1465-66 (1947).

12. Mendelson, Mr. Justice Frankfurter-Law and Choice, 10 VAND. L. Rev. 333, 334 (1957).

13. Rostow, Book Review, 56 Y AIE L.J. 1469 (1947). 
has declined. Controversy over whether Justice Black is an "activist" 14 has been at least partly displaced by the realization that the "Court is hard enough to understand and to predict, without forcing all analysis to choose between being pro- or anti-Mr. Justice Black."1s Similarly, the vexing question whether Justice Frankfurter is "a fallen liberal angel"16 has given way to more general awareness of the question's essential meaninglessness : in the performance of his duties, "Mr. Justice Frankfurter is . . . no more a conservative than he is a liberal. It is of the very essence of his judicial philosophy that his role as a judge precludes him from having a program couched in these terms of choice."17

Subtler and more persistent has been the notion that ex-professor Frankfurter "remained a rather narrow academician, engrossed in the trivia of formal legal propriety ... to the disregard of the tough stuff of judicial statesmanship."18 The charge was put most cuttingly a decade ago in Walton Hamilton's seductive elegy on the nine young men. "It does no good," he wrote charitably, "to impute personal blame. Mr. Justice Frankfurter has no feel for the dominant issues; he operates best when weaving crochet patches of legalism on the fingers of the case. He does the best he can, often very well indeed, with the techniques in which he is proficient; it is a calamity that his skills happen to be petty skills. He is the victim of a bad legal education ...."18

If faulty education has made it difficult for Frankfurter to cope with the "dominant issues," it has not been for want of good teachers. If it is true that "our present judges have gone to school . . . to Holmes and Cardozo,"20 it is especially true of the judge widely regarded on his appointment as "the right and unmistakable choice to fill the seat held by Cardozo and before him by Holmes."21

14. See Rodell, Book Review, 56 Yale L.J. 1462, 1465-66 (1947); Douglas, Mr. Justice Black: A Foreword, 65 YALE L.J. 449 (1956).

15. Rostow, Book Review, 56 Y YLE L.J. 1469 (1947).

16. Powell, Judicial Protection of Civil Rights, 29 Iowa L. Rev. 383, 394 (1944).

17. Jaffe, The Judicial Universe of Mr. Justice Frankfurter, 62 HAnv. L. Rev. 357, 358 (1949).

18. Rodell, Nine Men 271 (1955).

19. Hamilton, Book Review, 56 Y ALE L.J. 1458, 1460 (1947). In an abundance of generosity, Hamilton also outlined a variant and more courteous possibility-that Frankfurter was not so much stupid as malevolent. "Frankfurter affects a lack of concern for the 'end product'; yet his votes are to be predicted in terms of the end product. You can almost always tell where he is coming out; yet not even the faithful can tell in advance how his stand is to be legalized. Frankfurter spurns 'policy' and professes to lay the law down on the line. Yet he usually gets to the same place as Jackson whose law is not unspotted by the world. The work of the current term is marked by numerous instances of the search for a decent way of doing an indecent thing." Ibid.

20. FreUnd, ON Understanding the Supreme Courr 36 (1951).

21. Editorial, Justice Frankfurter, 148 The Nation 51, 52 (1939). Frankfurter, in "the last piece ... [he] wrote before he was nominated for membership on the Supreme Court," Frankfurter, Law and Politics 88 (1939), observed that "the history of the 
From his predecessors, Frankfurter probably did not acquire much of that "competence in the discussion of substantive questions," which, according to Walton Hamilton, "Douglas, Black, et al. have," but which Frankfurter shuns in order to "operate in the procedural field where he has confidence in his own footing." 22 To be sure, Frankfurter might have "gone to school" to his predecessors in substantive matters. For, as Frankfurter has pointed out, Holmes and Cardozo were themselves signal exceptions to the general rule that because "the raw materials of public law controversies are contemporary affairs . . . understanding of their significance is seldom achieved on the bench without considerable prior immersion in affairs."23 Nevertheless, what Frankfurter principally learned from Holmes and Cardozo related to matters of judicial method-the limitations which the judicial process imposes on those charged with its responsible exercise, especially in constitutional cases. Their scholarly and their judicial writings combined to instill in Frankfurter a sense of the importance of distinguishing "the austere responsibility of a judge from the ample discretion of the legislator,"24 and wakened an early understanding of why it "is a misfortune if a judge reads his conscious or unconscious sympathy with one side or the other prematurely into the law."'25 What Frankfurter inherited from Holmes and Cardozo were those habits of humility and restraint which they in their different ways-each building in some measure on the fundamental teachings of Professor Thayer ${ }^{26}$ - brought to the job of constitutional adjudication.

Supreme Court affords no analogue to the unanimity of lay as well as professional opinion that Chief Judge Cardozo was the one man adequate to fill the historic place vacated by Holmes." Frankfurter, Mr. Justice Cardozo and Public Law, 48 Y YLE L.J. 458 (1939), 39 Colum. L. Rev. 88 (1939), 52 Harv. L. Rev. 440 (1939), reprinted in FranKFuRTER, LAw AND Politics 88, 89 (1939) (hereinafter cited as Law and Politics).

22. Hamilton, Book Review, 56 Y XLE L.J. 1458, 1459-60 (1947).

23. Frankfurter, Mr. Justice Cardozo and Public Law, 48 Y ALE L.J. 458, 462 (1939), 39. Colum. L. Rev. 8S, 92 (1939), 52 Harv. L. Rev. 440, 444 (1939), reprinted in Law AND Polttics \$8, 92. See also Frankfurter, Mr. Justice Holmes and the Supreme Court 24 (1938).

"Throughout its history the Supreme Court has called for statesmanship-the gifts of mind and character fit to rule nations. The capacity to transcend one's own limitations, the imagination to see society as a whole, come, except in the rarest instance, from wide experience. Only the poetic insight of the philosopher can replace seasoned contact with affairs." Franthfurter \& Landis, The Business of the Supreme Court 317 (1928).

24. Frankfurter, MIr. Justice Cardoso and Public Lawe, 48 YALE L.J. 458, 471 (1939), 39 Colum. L. Rev. 88, 101 (1939), 52 HaRv. L. Rev. 440, 453 (1939), reprinted in LAw AND Politics 88, 95.

25. Holmes, Collected Legal Papers 295 (1921), quoted in Frankfurter, Mr. Justice Holmes and the Supreme Court 31 (1938).

26. See ThAyer, The Origin and Scope of the American Doctrine of Constitutional Lazi, in Legal Essays 1 (1908). This influence persists: "[T]hat James Bradley Thayer was no more when my class entered the School has been a lifelong bereavement for at least one member of that class." Frankfurter, Joseph H. Beale, 56 HARv. L. REv. 701, 702 (1943), reprinted in Frankfurter, Of Law and Men 265 (1956). 
From Brandeis-to whom he also went to school-Frankfurter learned further of restraint. "The history of the Court and the nature of its business admonish against needless or premature decisions. It has no greater duty than the duty not to decide or not to decide beyond its circumscribed authority."27 With Brandeis the principle was "absolutely basic."28 Rather than join the majority which upheld the sale of electric power by the Tennessee Valley Authority, ${ }^{29}$ or join what may for a time have been a majority ready to sustain the ill-fated Child Labor Tax Act,30 Brandeis would in both instances have subordinated what must have been strong predilections on the merits to his conviction that dismissal should be predicated on the plaintiffs' lack of standing to sue.

Brandeis's insistence on fidelity to jurisdictional limitations was partly a method for keeping lesser judges within the realms of competence from which he, Holmes and Cardozo so seldom strayed. But the insistence was also, as Frankfurter has noted, something more. "In view of our federalism and the Court's peculiar function, questions of jurisdiction in constitutional adjudications imply questions of political power."31 To overstep the limitations is not mere unwisdom, it is usurpation.

Performance of the Court's most delicate revisory task-the review of state court judgments- ${ }^{32}$ has, since Martin $v$. Hunter's Lessee ${ }^{33}$ and Cohens v. Virginia, ${ }^{34}$ largely depended on scrupulous adherence to jurisdictional limitations. "If it is found that no such [federal] question is raised or decided in the court below, then all will concede that ... [the writ] must be dismissed for want of jurisdiction."3s Moreover, when a federal question has been duly

27. Frankfurter, Mr. Justice Brandeis and the Constitution, 45 Harv. L. REv. 33, 79 (1931), reprinted in LAW AND PoLutics 113, 120. Frankfurter was plainly echoing Brandeis's remark to him: "The most important thing we do is not doing." BICKEL, THE Unpublis aed Opinions of Mr. Justice Brandeis 17 (1957).

28. Freund, Introduction to BICKEer, op. cit. supra note 27 , at xvi.

29. Ashwander v. TVA, 297 U.S. 288, 341 (1936).

30. Professor Bickel's extremely illuminating research into Brandeis's unpublished opinions suggests that the statute invalidated in 1922 in the Child Labor Tax Case, 259 U.S. 20 (1922), was nearly sustained in 1920, after the first argument in Atherton Mills v. Johnston, 259 U.S. 13 (1922), notwithstanding Brandeis's vehement jurisdictional objection to that earlier proceeding. Whether or not a majority would have voted to uphold the statute, Brandeis plainly would have done so had he been able to satisfy his jurisdictional scruples. But in 1922, he joined the majority which, in the Child Labor Ta.r Case, struck down the statute as an attempt to circumvent Hammer v. Dagenhart, 247 U.S. 251 (1918), in which Holmes, Brandeis and others had dissented. See BICKEI, op. cit. supra note 27 , at $1-20$.

31. Frankfurter, Mr. Justice Brandeis and the Constitution, 45 HARv. L. Rev. 33, 79 (1931), reprinted in LAw AND Politics 113, 120.

32. See Warren, Legislative and Judicial Attacks on the Supreme Court of the Unitcd States-A History of the Twenty-fifth Section of the Judiciary Act, 47 Arr. L. Rev. 1, 161 (1913).

33. 14 U.S. (1 Wheat.) 304 (1816).

34. 19 U.S. (6 Wheat.) 257 (1821).

35. Murdock v. Memphis, 87 U.S. (20 Wall.) 590, 627 (1875). 
"raised, and presented to the State court," the Supreme Court's appellate authority extends only to that question, not to the case as a whole. ${ }^{36}$

The classic example of steadfast application of these postulates is, of course, Brandeis's concurrence for Holmes and himself in the Whitney case. ${ }^{37}$ Miss Whitney had been found guilty of joining and helping to organize the California Communist Labor Party in violation of a criminal syndicalism act which-in terms not unprophetic of the present Smith Act-banned organization of, or knowing membership in, any group formed "to advocate, teach or aid and abet criminal syndicalism," a doctrine espousing violence "as a means of accomplishing a change in industrial ownership or control, or effecting any political change."3s In the state courts, her lawyers had made a general constitutional challenge to the validity of the statute as applied. The Court majority, through Justice Sanford, found no difficulty in sustaining the inhibition on Miss Whitney's freedom of speech as a reasonable exercise of California's police power. For Brandeis and Holmes, whose "opinion ... seems destined to live as long as the ideals of democracy survive,"39 Miss Whitney's case cut deeper. "Men feared witches and burnt women. It is the function of speech to free men from the bondage of irrational fears. . . . Only an emergency can justify repression. ... The fact that speech is likely to result in some violence . . . is not enough to justify suppression. There must be the probability of serious injury to the State." 40

"Whether, in 1919, when Miss Whitney did the things complained of, there was in California such clear and present danger of serious evil, might have been made the important issue in the case"41_might have been, but had not been. Miss Whitney's lawyers had not, in the state courts, sought directly to overcome the "testimony which tended to establish . . . a conspiracy ... to commit present serious crimes; and likewise to show that such a conspiracy would be furthered by the activity of the society of which Miss Whitney was a member."42 Counsel's technical error was beyond the power of Brandeis and Holmes to repair:

"Our power of review ... is limited not only to the question whether a right guaranteed by the Federal Constitution was denied ... but to the particular claims duly made below, and denied. . . . We lack here the power occasionally exercised on review of judgments of lower federal courts to correct . . . vital errors, although the objection was not taken in the trial court. ... This is a writ of error to a state court. Because we may not enquire into the errors now alleged, I concur in affirming the judgment ....".43

36. Id. at 635-36.

37. Whitney v. California, 274 U.S. 357, 372 (1927). See Freund, ON UNDERSTANDing the Suprenie Courr 62 (1951); Mendelson, supra note 12, at 333; Bickel, op. cit. supra note 27 , at 17 .

38. 274 U.S. at 360 .

39. Mendelson, supra note 12 , at 333.

40. 274 U.S. at 376-78.

41. Id. at 379 .

42. Ibid.

43. Id. at 380 . 
In the Terminiello case in 1949, Frankfurter revealed himself the bondslave of similar technicalities. ${ }^{44}$ The defendant, an unfrocked priest allied with Gerald L. K. Smith, addressed a large public meeting in Chicago; using vicious invective and innuendo, he called on "Fellow Christians" to resist an alleged Jewish-Communist revolution led by Eleanor Roosevelt, Henry Wallace, Henry Morgenthau and others. His speech was widely advertised. During its course, a counterdemonstration of some fifteen hundred persons milled about outside, breaking windows, manhandling persons entering the hall and yelling insults at those within. Terminiello's highly provocative speech, delivered to those inside the hall in this inflamed context, was the basis for a conviction under the municipal ordinance relating to disorderly conduct. The argument in the Supreme Court "focused on the issue of whether the content of petitioner's speech was composed of derisive, fighting words, which carried it outside the scope of the constitutional guarantees." 45 But Justice Douglas, speaking for a majority composed of himself and Justices Black, Reed, Murphy and Rutledge, found it unnecessary to "reach that question, for there is a preliminary question that is dispositive of the case."40 The "preliminary question" arose from the trial judge's construction of the ordinance; his charge to the jury permitted conviction if Terminiello's speech were found to be one which "stirs the public to anger, invites dispute, brings about a condition of unrest, or creates a disturbance." 47 Douglas asked whether this charge had not authorized a guilty verdict predicated not at all upon the constitutionally requisite finding that the defendant had uttered "fighting words" 48 which might have triggered a riot.

Thus framing the preliminary question, Douglas easily answered it in Terminiello's favor. A conviction that might lie within so wide an ambit could not stand, for "a function of free speech under our system of government is to invite dispute. It may indeed best serve its high purpose when it induces a condition of unrest, creates dissatisfaction with conditions as they are, or even stirs people to anger." 49

The only difficulty with Douglas's disposition of the case-a reiteration of "generalized approbations of free speech with which, in the abstract, no one will disagree"50 - is that the decisive preliminary question was not properly before the Supreme Court. As Frankfurter observed in dissent, it was "not raised by counsel in the Illinois courts, not made the basis of a petition for certiorari here-not included in the 'Questions Presented,' nor in the 'Reasons Relied On for the Allowance of the Writ'-and explicitly disavowed at the bar of this Court." 51

44. Terminiello v. Chicago, 337 U.S. 1, 8 (1949) (dissenting opinion).

45. Id. at 3.

46. Ibid.

47. Ibid.

48. See Chaplinsky v. New Hampshire, 315 U.S. 568 (1942).

49. 337 U.S. at 4.

50. Id. at 13 (dissenting opinion of Jackson, J.).

51. Id. at 9. Chief Justice Vinson, in dissent, said the question "was no part of the 
Douglas felt that since Terminiello had challenged the application of the ordinance to his conduct, attaching importance to his failure to challenge the trial court's construction of the statute would be to "strain at technicalities."52 And he cited Stromberg $v$. California-the Red Flag case-to prove his point. ${ }^{\text {.3 }}$ But Stromberg-as Frankfurter and Chief Justice Vinson pointed out ${ }^{54}$-is little comfort; more precisely, it is authority to the contrary. The case involved a prosecution under a statute making it a felony to display a red flag "as a sign, symbol or emblem of opposition to organized government or as an invitation or stimulus to anarchistic action or as an aid to propaganda that is of a seditious character." "5s The defendant attacked the statute as an abridgment of free speech and raised no separate objection to the judge's instructions that adopted the disjunctive language of the statute, rather than the conjunctive language of the information. The state appellate court sustained the statute and the conviction because, as it explicitly determined, at least one of the three possible bases of conviction was in its view constitutionally permissible. The Supreme Court, turning the syllogism around, reversed because the first of the possible bases of conviction was "invalid on its face," 56 and a general verdict that might have rested upon it could not be sustained. Stromberg, in short, was a case in which the exact federal question raised and decided below-the alleged invalidity of specific statutory language adopted by the trial judge and perhaps relied upon by the jury-was the exact federal question reviewed by the Supreme Court. It is hardly authority for the proposition that the Supreme Court can review language employed by the trial judge which departs from challenged statutory language and which is never separately brought in question before any state court. ${ }^{57}$

"The relations between ... state and federal government raise ... questions all of which can and, indeed, must be treated by a conscientious judge as questions of jurisdiction. The 'liberal' may, it is true, ask simply whether the law in question is a good or a bad one. . . But to Mr. Justice Frankfurter such questions as these, at least at the threshold, concern the respective spheres of governmental power." 58

case until this Court's independent research ferreted it out of a lengthy and somewhat confused record." Id. at 7.

52. Id. at 6 .

53. 283 U.S. 359 (1931).

54. 337 U.S. at $7,9-10$.

55. 283 U.S. at 361 . (Emphasis added.)

56. Id. at 370 .

57. These observations do not impinge on the quite irrelevant doctrine that a state court's construction of a state statute-however discrepant it may appear-is binding on the federal courts. Terminiello's initial challenge to the ordinance preceded the instruction which gave such unanticipated latitude to the ordinance. After conviction, Terminiello persisted in his attack on the ordinance but without ever directing any appellate court's attention to the breadth the ordinance had assumed at trial. The inference is hardly reasonable, therefore, that the Illinois appellate courts approved and measured against the Fourteenth Amendment the trial court's unchallenged interpretation of the ordinance as a proscription on utterance which "invites dispute."

58. Jaffe, The Indicial Universe of Mr. Justice Frankfurter, 62 HARv. L. REv. 357, 378-79 (1949). 
Thus, for Frankfurter, the course adopted by the Terminiello majority struck at the foundations of judicial responsibility:

"Only the uninformed will deride as a merely technical point objection to what the Court is doing in this case. The matter touches the very basis of this Court's authority in reviewing the judgments of State courts. . . . The relation of the United States and the courts of the United States to the States and the courts of the States is a very delicate matter. It is too delicate to permit silence when a judgment of a State court is reversed in disregard of the duty of this Court to leave untouched an adjudication of a State unless that adjudication is based upon a claim of a federal right which the State has had an opportunity to meet and to recognize. If such a federal claim was neither before the State court nor presented to this Court, this Court unwarrantably strays from its province in looking through the record to find some federal claim that might have been brought to the attention of the State court and, if so brought, fronted, and that might have been, but was not, urged here. This is a court of review, not a tribunal unbounded by rules. We do not sit like a kadi under a tree dispensing justice according to considerations of individual expediency."59

As a practical matter, what the Terminiello majority did was to decide a case that not only was not before it but that had never, in any adversary sense, existed anywhere. By bringing the powerful artillery of free speech to bear on the trial court's unchallenged instructions, the majority spared itself the difficult task of measuring that fundamental freedom against the actual content and context of Terminiello's speech. The majority was thus able, wrote Justice Jackson, to judge "Terminiello's speech . . . as if he had spoken to persons as dispassionate as empty benches, or like a modern Demosthenes practicing his Philippics on a lonely seashore."60

Why did Douglas and his brethren of the majority indulge in this shadow play? One can only conjecture; but certain inferences may be in order. As judges deeply committed to the principles of the First Amendment, they must have been profoundly concerned at imposing criminal sanctions on the making of a political speech, however obnoxious. On the other hand, the five Justices may have found great difficulty in agreeing on a rationale for denying municipal power to punish conduct which could well have precipitated widespread violence. The avenue of escape which Douglas found was to decide not the case reviewed by the Illinois appellate courts but another and less exacting case which would not ruffle the placid waters of the First Amendment. And, fortuitously, such a case was at hand-one that counsel could have, but had not, brought to the Supreme Court. To refrain from deciding the tractable case, to insist on deciding the case actually presented, merely because of notions that the Court's "power of review . . . is limited . . . to the particular claims duly made below, and denied," 61 would be to "strain at technicalities." 02

59. 337 U.S. at $10-11$.

60. Id. at 13 .

61. Whitney v. California, 274 U.S. 357, 380 (1927) (concurring opinion).

62. 337 U.S. at 6. 
After all, if one had, in Waiton Hamilton's words, any "feel for the dominant issues," ${ }^{63}$ the trial court's instructions were plainly unsupportable and should have been so declared. "Where Frankfurter was the circumspect backer-away from issues, Douglas, like Brandeis, his predecessor in crusade, wanted always to hit them head-on." 84

Terminiello, decided eight years ago, was a test of judicial responsibility. ${ }^{65}$ It has its current analogue in Sweezy $v$. New Hampshire. ${ }^{66}$ Sweezy was a companion case to Watkins $v$. United States ${ }^{67}$-a companion in that both cases were set for argument together, were decided on the same day and involved contempt convictions for refusal to answer questions about alleged left-wing activity or belief.

In Watkins, defendant, a union organizer, refused to answer questions put to him by the Un-American Activities Committee about persons who may once have been communists but, to his best knowledge, no longer were. The Court, in an opinion by Chief Justice Warren, joined by Justices Black, Frankfurter, Douglas, Harlan and Brennan, concluded that the purposes of the investigation were too vague to permit the witness to know whether the questions were relevant. ${ }^{B 8}$ Accordingly, on Fifth Amendment due process grounds, the conviction was reversed.

The Chief Justice also wrote the prevailing opinion in Sweezy. Professor Sweezy had refused to answer certain questions asked by the Attorney General of New Hampshire pursuant to a legislative mandate to investigate subversion. The questions centered upon Sweezy's alleged advocacy of Marxism or related doctrines in a lecture delivered at the University of New Hampshire, and upon his wife's and others' involvement in the Progressive Party and the Progressive Citizens of America. The Chief Justice, in an opinion joined by Justices Black, Douglas and Brennan, expressed grave and eloquent concern at the questions' apparent trespass upon reserved fields of academic freedom and political belief. "We do not," said Warren, "now conceive of any circumstance wherein a state interest would justify infringement of rights in these fields. But we do not need to reach such fundamental questions of state power to decide this case." 69

Ultimate issues could be avoided because the legislative mandate was so general that the Court could not conclude that the New Hampshire legislature

63. See text at note 19 supra.

64. RODELL, NINE MEN 273 (1955).

65. Two proper choices lay before the Court in Terminiello. The case might have been decided on the "fighting words" basis on which the Illinois courts treated it. See Vinson's dissent, 337 U.S. at 7. This choice was favored by Vinson, Frankfurter, Jackson and Burton, but their feeling that the facts warranted affirmance is, in the writer's view, erroncous. The alternative was to dismiss the writ of certiorari as improvidently granted.

66. 354 U.S. 234 (1957).

67. 354 U.S. 178 (1957).

68. Justice Clark dissented; Justices Burton and Whittaker did not participate. Justice Frankfurter, having joined the Chief Justice's opinion, also concurred separately.

69. 354 U.S. at 251. 
regarded the Attorney General's questions as essential to the security of the state.

"Petitioner had been interrogated by a one-man legislative committee, not by the legislature itself.

“....

“... The lack of any indications that the legislature wanted the information the Attorney General attempted to elicit from petitioner must be treated as the absence of authority. It follows that the use of the contempt power, notwithstanding the interference with constitutional rights, was not in accordance with the due process requirements of the Fourteenth Amendment."70

Frankfurter's concurrence, like his dissent in Terminiello, reached the real merits of the controversy. Warren's rationale was untenable, for the finding of the New Hampshire Supreme Court that Attorney General Wyman was acting in accordance with authority duly delegated to him was a matter of state law which the Supreme Court was powerless to review. The Court's opinion in Dreyer $v$. Illinois ${ }^{71}$ had, as Frankfurter pointed out, ${ }^{72}$ long ago put any such issue beyond federal scrutiny:

"Whether the legislative, executive and judicial powers of a State shall be kept altogether distinct and separate, or whether persons or collections of persons belonging to one department may, in respect to some matters, exert powers which, strictly speaking, pertain to another department of government, is for the determination of the State. And its determination one way or the other cannot be an element in the inquiry whether the due process of law prescribed by the Fourteenth Amendment has been respected by the State or its representatives when dealing with matters involving life or liberty."73

Forced to turn to the merits-the power of New Hampshire to exact answers to the questions propounded-Frankfurter wrote an historic affirmation of the primacy of free scholarly inquiry and free political discussion and activity. As against those interests, the justifications urged by New

70. Id. at $251-52,254-55$.

71. 187 U.S. 71 (1902).

72. 354 U.S. at $256-57$.

73. 187 U.S. at 84 . Warren acknowledged the rule but seemed to regard it as no bar to his decision. 354 U.S. at 255 . The rationale of the Sweezy majority provoked quaint but perhaps not wholly inappropriate response in New Hampshire. The Swecry case was decided on June 17, 1957. On July 10, 1957, the New Hampshire House and Senate, "in general court convened," declared by way of joint resolution that "this general court is, and for a long time has been, familiar with the questions put to Paul M. Sweezy by the attorney general acting in this state, authorized these questions, wanted and continues to want the information which is sought by these questions, and has enacted this resolution for the specific purpose of removing the doubt which has been expressed by the United States Supreme Court." Sweezy v. New Hampshire, October 1956 Term, No. 175, Petition for Rehearing 2. Armed with this retrospective vindication by his legislature, Attorney General Wyman sought rehearing, but rehearing was denied at the start of the 1957 Term. 78 Sup. Ct. 7 (1957). 
Hampshire for invading Sweezy's privacy seemed to Frankfurter and Harlan paltry and insubstantial.

"[S]triking the balance implies the exercise of judgment. This is the inescapable judicial task in giving substantive content, legally enforced, to the Due Process Clause, and it is a task ultimately committed to this Court. ... Such a judgment must be arrived at in a spirit of humility when it counters the judgment of the State's highest court. But in the end, judgment cannot be escaped-the judgment of this Court."'74

\section{Expounding a Constitution}

Escape from judgment may be hard, but the prevailing opinions managed it in Terminiello and in Sweezy. Frankfurter, in each instance unable to find judicial power to utilize an attractive detour around decision, was compelled to grapple with the case on its "merits"-to resolve the genuinely "dominant issues." But in these and hundreds of other cases, the problem Frankfurter regards as no less significant than the substantive controversy is the sometimes "technical" question whether the controversy can and should be resolved by the Court.

Thus it is that Frankfurter "is forever disposing of issues by assigning their disposition to some other sphere of competence."7s On a national level, judicial deference to Congress and the administrative agencies-forums of primary responsibility and, hopefully, greater expertise-is, for Frankfurter, a vital aspect of the separation of powers. On a state level, Frankfurter's federalism dictates extreme reluctance to interfere unnecessarily in local policies and processes, judicial or otherwise. In each instance, plainly enough, Frankfurter feels that "dispersion of the power to govern . . . . is the essence of our system." "76 And complementary factors also come into play: a reluctance to use precious judicial time on minor matters which can be or have already been more profitably canvassed elsewhere, ${ }^{77}$ and an insistence on scrupulous adherence to the Court's "settled tradition against needlessly pronouncing on constitutional issues."78

74. 354 U.S. at 267.

75. Jaffe, supra note 58 , at 359 .

76. Mendelson, Mr. Justice Frankfurter-Laa' and Choice, 10 VANd. L. Rev. 333, 336 (1957).

77. See, c.g., Frankfurter's dissent in Rogers v. Missouri Pac. R.R., 352 U.S. 500, 524 (1957). Compare his vigorous fidelity to Brandeis's decision in Erie R.R. v. Tompkins, 304 U.S. 64 (1938) -a manifestation both of Frankfurter's deference to state authority in fields reserved to the states and of his impatience with a vast category of private litigation which federal courts have neither the time, the day-to-day competence nor the prime authority to handle in fruitful fashion. See Guaranty Trust Co. v. York, 326 U.S. 99 (1945) ; Angel v. Bullington, 330 U.S. 183 (1947) ; cf. Bank v. Parnell, 352 U.S. 29 (1956).

78. Frankfurter, John Marshall and the Judicial Function, 69 Harv. L. Rev. 217, 235 (1955), reprinted in Frankfurter, OF LAw AND MeN 3, 25 (1956). See Frankfurter's dissenting opinion in Eisler v. United States, 338 U.S. 189, 190 (1949), protesting the unwillingness of the Court to dismiss the writ of certiorari, rather than "merely postpone review indefinitely," where the defendant had fled the country after argument 
In short, a major part of Frankfurter's judicial energy is spent in drawing lines between what should and what should not be judged. There may be ample room for disagreement with his emphases. But the process is one which itself calls for judgments which no aware judge can conscientiously escape.

When Frankfurter determines that he must address himself to the ultimate substantive issues, he is, of course, guided by canons of judicial restraint as compelling as those that caution him against reaching such issues before they are duly presented. "If judges want to be preachers, they should dedicate themselves to the pulpit; if judges want to be primary shapers of policy, the legislature is their place. Self-willed judges are the least defensible offenders against government under law."79

Especially is this true of Justices exercising the Supreme Court's power, under the Fourteenth Amendment's due process clause, to veto state action. A generation ago, Frankfurter felt that the power "ought to go."80 The vicarious partner in so many Holmes and Brandeis dissents perceived that the words of the amendment "mean what the shifting personnel of the United States Supreme Court from time to time makes them mean. The inclination of a single Justice, the tip of his mind-or his fears-determines the opportunity of a much-needed social experiment to survive, or frustrates, at least for a time, intelligent attempt to deal with a social evil." 81 Nor did the possibility of occasional invalidation of state restrictions on free inquiry and expression alter the arithmetic-he viewed "the cost of this power of the Supreme Court on the whole as greater than its gains."82 And, in any event, "the real battles of liberalism are not won in the Supreme Court" but through "a persistent, positive translation of the liberal faith into the thoughts and acts of the community." 83

and before decision; later the writ was dismissed. Eisler v. United States, 338 U.S. 883 (1949).

It is noteworthy that Frankfurter contributed to the Encyclopaedia of Social Sciences both the article entitled Supreme Court, United States, 14 EncycLopaedia of Social. ScIences 474 (1934), and the article entitled Advisory Opinions, 1 id. at 475. But even Frankfurter has not been able wholly to refrain from excursions into constituttional essays not required by the case before him. See Association of Westinghouse Salaried Employees v. Westinghouse Elec. Corp., 348 U.S. 437 (1955); cf. Textile Workers Union v. Lincoln Mills, 353 U.S. 448, 469-84 (1957) (dissenting opinion). See Bickel \& Wellington, Legislative Purpose and the Judicial Process: The Lincoln Mills Case, 71 Harv. L. Rev. 1, 38 (1957).

79. Frankfurter, John Marshall and the Judicial Function, 69 Harv. L. REv. 217, 238 (1955), reprinted in Frankfurter, OF Law and MEN 3, 29 (1956).

80. Frankfurter, The Red Terror of Judicial Reform, 40 NEw RePuBLIc 110, 113 (1924), reprinted in LAw AND Politics 10, 16. Apparently, Frankfurter felt the same about Fifth Amendment due process as a veto on federal action, for his exact words were that "the due process clauses ought to go."

81. Frankfurter, Can the Supreme Court Guarantee Toleration?, unsigned editorial, 43 New Republic 85, 86 (1925), reprinted in Law and Politics 195, 196.

82. Ibid., reprinted in LAW AND Politics at 196-97.

83. 43 id. at 87 , reprinted in LAW AND PoLITTCS at 197. Frankfurter echoed himself years later, dissenting West Virginia State Bd. of Educ. v. Barnette, 319 U.S. 624, 670-71 (1943). With Barnette, compare cases cited notes $87-89$ infra. 
As a judge, Frankfurter of course accepted the due process clause and acquiesced in that view of its scope which Brandeis and Holmes at last acknowledged: "Despite arguments ... which had seemed ... persuasive, it is settled that the due process clause of the Fourteenth Amendment applies to matters of substantive law as well as to matters of procedure."84 And, for Frankfurter, due process of law means that amalgam of rights, substantive and procedural alike, which, in Cardozo's phrase, inhere in "the concept of ordered liberty."

Situations in which Frankfurter has found violations of substantive due process have been, not too surprisingly, infrequent. Sweezy is one recent instance. $^{80}$ Everson, ${ }^{87} \mathrm{McCollum}^{88}$ and Zorach $v$. Clauson ${ }^{89}$-the trilogy of cases on separation of church and school-collectively form a second. The

S4. Whitney v. California, 274 U.S. 357, 373 (1927) (concurring opinion).

85. Palko v. Connecticut, 302 U.S. 319, 325 (1937).

86. Black and Douglas, who were unwilling to go as far as Frankfurter in Sweezy, have, of course, been the firmest members of the Court in their insistence on protecting free speech and related rights. See, e.g., their dissenting opinions in Dennis v. United States, 341 U.S. 494, 579, 581 (1951). The quarrel over whether free speech occupies a "preferred position"-see, e.g., the concurrence by Frankfurter and the dissent by Rutledge in Kovacs v. Cooper, 336 U.S. 77, 89-97, 104-06 (1949)-deriving largely from intimations in the famous Carolene Products footnote, United States v. Carolene Products Co., 304 U.S. 144, 152 n.4 (1938), may perhaps now be recognized as a principally verbal dispute in view of Frankfurter's statement in Sweezy: "In the political realm, as in the academic, thought and action are presumptively immune from inquisition by political authority." 354 U.S. at 266. Compare Professor Cahn's tribute to Black, Cahn, The Firstness of the First Amendment, 65 YALE I.J. 464, 471 (1956), and Frankfurter's observation for the Court in Ullman v. United States, 350 U.S. 422, $428-29$ (1956) : "To view a particular provision of the Bill of Rights with disfavor inevitably results in a constricted application of it. This is to disrespect the Constitution." But whatever view be taken of the firstness of the First Amendment, the secondness of the Second Amendment is demonstrable. See United States v. Miller, 307 U.S. 174 (1939).

Warren has given signs of sharing the Black-Douglas commitment to free speech. See, e.g., International Brotherhood of Teamsters v. Vogt, Inc., 354 U.S. 284 (1957), in which Frankfurter sustained an injunction against picketing, and Douglas wrote a dissent on free speech grounds in which Warren and Black joined. Each of the Vogt opinions is a signal example of failure fully to come to grips with the Court's prior positions: contrast Frankfurter's retrospective emasculation of his (today untenable) reversal of an injunction against peaceful picketing in AFL v. Swing, 312 U.S. 321 (1941), with Douglas's reluctance to acknowledge that Black's opinion for a unanimous Court in Giboney v. Empire Storage \& Ice Co., 336 U.S. 490 (1949), is the foundation for current Supreme Court acquiescence in state restraints on peaceful picketing. Compare Youngdahl v. Rainfair, Inc., 26 U.S.L. WeEK 4031 (U.S. Dec. 9, 1957), illustrating the use, in labor disputes affecting interstate commerce, of preemption rather than the weary free speech doctrines as a rationale for voiding state injunctions against peaceful picketing.

87. Everson v. Board of Educ., 330 U.S. 1 (1947). Frankfurter was one of four Justices dissenting from Black's view that a New Jersey community could subsidize bus service to Catholic schools.

S8. Illinois $e x$ rel. MIcCollum v. Board of Educ., 333 U.S. 203 (1948). Frankfurter, for the four Everson dissenters, concurred in invalidating the Champaign, Illinois program permitting religious instruction during public school class hours.

89. 343 U.S. 306, 320 (1952). Frankfurter dissented from Douglas's opinion sustaining the New York "released time" program. 
dissent of Frankfurter and Douglas in International Harvester v. Goodrich is a significant third instance, for it serves as a reminder that substantive due process protects property rights as well as civil liberties. ${ }^{90}$ Finally, the School Cases might have constituted another instance resolved on due process grounds, had equal protection not been an available rationale. ${ }^{91}$ None of these illustrates judicial timidity or a lack of understanding of "dominant issues."

Nor does lack of courage or insight characterize Frankfurter's approach to procedural due process. Particularly, the great Adamson ${ }^{92}$ debate-in which the Court rejected the Black-Douglas-Murphy-Rutledge view that the Fourteenth Amendment makes applicable to the states all the specific limitations of the first eight amendments ${ }^{93}$ - has been considerably less significant on a

90. 350 U.S. 537,548 (1956). The case tested the validity of the priority given a New York tax lien on certain heavy vehicles using New York highways and therefore subject to a state highway use tax. Frankfurter and Douglas objected to giving priority to the tax liens as against the interest of the conditional vendor in certain of the vehicles where the tax liabilities and hence the liens arose from the operation by the conditional vendee of other vehicles prior to the conditional purchase of the vehicles involved. Douglas's position suggests his tacit abandonment of his (and Black's) occasional view that corporations are not "persons" protected by the Fourteenth Amendment. Sce Wheeling Steel Corp. v. Glander, 337 U.S. 562, 576 (1949) (dissenting opinion), and the separate opinion of Jackson, id. at 574. See also Black's dissent in Connecticut Gen. Life Ins. Co. v. Johnson, 303 U.S. 77, 87 (1938).

91. See Bolling v. Sharpe, 347 U.S. 497 (1954); cf. Brown v. Board of Educ., 347 U.S. 483, 495 (1954). The equal protection clause has a specificity of function which might seem to make it a readier weapon-although of more limited scope-than its companion due process clause. In regulatory cases not involving race distinctions, however, both Frankfurter and Black have displayed a readiness to sustain the reasonableness of challenged classifications which parallels their deeply ingrained resistance to invalidating state action on due process grounds. Compare Goesaert v. Cleary, 335 U.S. 464 (1948) (Frankfurter opinion, in which Black joined, sustaining Michigan statute prohibiting a woman from acting as a barmaid unless she is "the wife or daughter of the male owner"), with Morey v. Doud, 354 U.S. 457 (1957) (invalidating, over dissents by Black, and by Frankfurter and Harlan, an Illinois statute regulating "currency exchanges" engaged in selling money orders, because the American Express Company was specifically exempted from the regulatory scheme). Douglas joined Rutledge and Murphy in dissent in Goesaert v. Cleary and joined Burton's opinion for the Court in Morcy v. Doud.

A decision with which Black and Frankfurter should feel increasing dissatisfaction upon continued reflection is Kotch v. Board of River Pilot Comm'rs, 330 U.S. 552 (1947), sustaining the nepotistic Louisiana practice for licensing pilots at the port of New Orleans. The decision for the Court was by Black; Rutledge, joined by Reed, Douglas and Murphy, dissented. It is hard to suppose that Black and Frankfurter would have sustained the application of similar criteria, for example, to admission to the bar. Comparc, as to exclusions from the bar invalidated on due process grounds, Schware v. Board of Bar Examiners, 353 U.S. 232, 248 (1957) (concurring opinion); Konigsberg v. State Bar, 353 U.S. 252 (1957). (Frankfurter dissented from the latter decision because of the "technicality" that the record was ambiguous as to whether the federal question had been passed on by the state court.) Cf. In re Summers, 325 U.S. 561 (1945).

92. Adamson v. California, 332 U.S. 46 (1947).

93. See Black's dissenting opinion, $i d$. at 68. Murphy and Rutledge were "not prepared to say that the latter [the first section of the Fourteenth Amendment] is entirely and necessarily limited by the Bill of Rights." Id. at 124. Moreover, even Black and 
practical than a conceptual level. And this is especially true of the differences separating the chief protagonists-Frankfurter on the one hand, Black and Douglas on the other. ${ }^{94}$ Probably the major single difference of view is on the necessity of counsel in state criminal proceedings. Following Powell $v$. Alabama ${ }^{95}$ and Betts $v$. Brady, ${ }^{96}$ Frankfurter finds due process offended by lack of counsel only in capital cases or where the likelihood of resultant prejudice is susceptible of fairly ready inference. ${ }^{97}$ Distaste for an issue about which he may feel on shaky ground ${ }^{98}$ perhaps explains the unpersuasive dogmatism which, on occasion, Frankfurter has invoked to find the right to counsel issue not properly presented. ${ }^{99}$

Frankfurter's present readiness to join Court majorities ruling confessions coerced ${ }^{100}$ represents a marked shift from the rigidity of the Ashcraft dissent

Douglas "are not content . . . to rest on the specific guarantees of the first eight Amendments." Freund, On Understanding the Suprenie Court 32-33 (1949). See also John Frank's discussion (Book Review, 24 IND. L.J. 139, 144 n.10 (1948)), to which Professor Freund refers.

94. Burton is the only other member of the Adamson Court still sitting.

95. 287 U.S. 45 (1932).

96. 316 U.S. 455 (1942).

97. See Foster v. Illinois, 332 U.S. 134, 137-38 (1947) ; Jaffe, The Judicial Universe of Mr. Justice Frankfurter, 62 HaRv. L. Rev. 357, 403 (1949).

98. Compare Freund, On Understanding the Supreare Court 35 (1949): "One may hope that a majority of the Court will turn to the view that the appointment of counsel is as indispensable to the just and evenhanded administration of the criminal law in the state courts as in the federal courts. They would be helped to reach this conclusion by avowing frankly that the Sixth Amendment does not furnish the real reason for the requirement in the federal courts. It seems more nearly true to regard that Amendment as having simply conferred the right on the accused to employ counsel-a right which of course was by no means assured prior to the adoption of the Constitution. If the right to have counsel appointed in the federal courts is acknowledged to rest on a pervasive sense of justice, it should be extended to state prosecutions as an element of due process of law. This would be a happy denonement of the dramatic, the over-dramatic, clash over the Fourteenth Amendment which has drawn so heavily on the energies of the Court." Perhaps a majority of the Court is pushing toward Professor Freund's result, without altering prevailing doctrines, by requiring less rigorous proof of resultant prejudice. See Moore v. Michigan, 26 U.S.L. WeEk 4023 (U.S. Dec. 9, 1957).

99. See Gayes v. New York, 332 U.S. 145 (1947), in which Frankfurter held that an attempt to vacate, on lack of counsel grounds, petitioner's first New York conviction as a prelude to obtaining modification of a subsequent second-offender sentence, was a "flank attack" the Court would not entertain, notwithstanding the fact that the course petitioner pursued appeared to be the one indicated by the then applicable state court decisions. In the right to counsel cases, Frankfurter has shown a reluctance to take advanced positions which "would furnish opportunities hitherto uncontemplated for opening wide the prison doors of the land." Foster v. Illinois, 332 U.S. 134, 139 (1947). The Court, in breaking new due process ground, is not, however, compelled to give its holdings retroactive effect. See the limitation imposed by Frankfurter's concurrence in Griffin v. Illinois, 351 U.S. 12, 25 (1956). Compare the postponed enjoyment of the constitutional rights proclaimed in the School Cases. Brown v. Board of Educ., 349 U.S. 294 (1955).

100. See Fikes v. Alabama, 352 U.S. 191, 198 (1957) (concurring opinion); Watts v. Indiana, 338 U.S. 49 (1949); Haley v. Ohio, 332 U.S. 596, 601 (1948) (concurring upinion). 
in which he concurred. ${ }^{101}$ But he has had greater trouble with the somewhat related problem of search and seizure. In $W$ olf $v$. Colorado, ${ }^{102}$ he spoke for the Court in finding the Fourth Amendment's prohibition a part of "the concept of ordered liberty" and hence binding on the states; ${ }^{103}$ but his "consensus of society's opinion which . . . is the standard enjoined by the Constitution"104 persuaded him that exclusion of illegally seized evidence was not a remedy so widely accepted as to constitute a constitutional mandate for the guidance of state courts. Rather, it was simply a rule of evidence devised by and for federal courts. This distinction, acceptable to Black but not to Douglas, ${ }^{100}$

101. In Ashcraft v. Tennessee, 322 U.S. 143, 174 (1944), Jackson, dissenting for himself, Roberts and Frankfurter from reversal of a conviction based on a confession provoked by thirty-six consecutive hours of questioning of a defendant held incommunicado, wrote the following heroically inapposite words: "The use of the due process clause to disable the States in protection of society from crime is quite as dangerous and delicate a use of federal judicial power as to use it to disable them from social or economic experimentation."

102. 338 U.S. 25 (1949).

103. See note 85 supra and accompanying text. Frankfurter's view of the importance of the Fourth Amendment's protection is impressively illustrated by his dissent in Harris v. United States, 331 U.S. 145, 155 (1947). As Frankfurter makes plain in his repeated protests against wiretapping and kindred practices, his feelings on this score are traceable to his early years as an assistant to Henry L. Stimson, when Mr. Stimson was United States Attorney for the Southern District of New York. "The third degree, search without warrant, wiretapping and the like, were not tolerated in what was probably the most successful administration in our time of the busiest United States Attorney's office." On Lee v. United States, 343 U.S. 747, 761 (1952) (dissenting opinion). It is reported that Mr. Stimson, as Secretary of State under President Hoover, closed down a secret intelligence unit in the State Department on the ground that "A gentleman does not look at someone else's mail." Esquire, Sept. 1957, p. 32.

104. Louisiana ex rel. Francis v. Resweber, 329 U.S. 459, 471 (1947) (concurring opinion).

105. Black concurred in Wolf, 338 U.S. at 39. Douglas, Murphy, and Rutledge dissented, $i d$. at $40,41,47$, each believing that the exclusionary rule was a constitutional mandate. The complex evolution of the rule lends support to the dissenters. See Note, 56 Y ALE L.J. 1076, 1077-78 n.11 (1947) : "In Boyd v. United States, 116 U.S. 616 (1SS6), where the Court invalidated a federal statute providing for the subpoena of personal records in a forfeiture proceeding, dictum of the a fortiori variety suggested that evidence seized without a warrant was clearly inadmissible, $i d$. at 633 , a departure from the established common-law rule that courts will not question the legality of acquisition of otherwise competent evidence. Williams v. State, $100 \mathrm{Ga}$. 511, 28 S. E. 624 (1897); see Commonwealth v. Dana, 2 Metc. 329, 337-8 (Mass. 1841). The issue was not relitigated before the Court for eighteen years; then, in Adams v. New York, 192 U.S. 585 (1904), the Court, although holding the challenged seizure not unconstitutional, appeared by dictum inserted arguendo, id. at 594-9, to repudiate the dictum of the Boyd case. The Adams decision was thought to have buried what seemed at most a momentary heresy. See United States v. Wilson, 163 Fed. 338, 340-4 (C.C.S.D.N.Y. 1908). Ten years later, however, in Weeks v. United States, 232 U.S. 383 (1914), Justice Day explained for the unanimous Court that his opinion in the unanimous Adams decision had merely precluded the litigation of illegal seizure at trial, and that unconstitutionally seized evidence was inadmissible where a motion to suppress was made in advance of trial. Subsequently the Court permitted exclusion at trial where the defendant had no knowledge of the unlawful seizure 
has returned to plague the Court-and especially Frankfurter. Thus, in Rochin, Frankfurter with some difficulty articulated the Court's view that California could not, consistently with due process, put in evidence against a defendant tried for possession of narcotics, the eminently trustworthy heroin extracted from the defendant's stomach by a stomach pump. ${ }^{106}$ In Irvine, Frankfurter in dissent protested the propriety of admitting in evidence incriminating conversations overheard by "bugging" defendant's apartment. ${ }^{107}$ But at the past term of Court, Frankfurter silently acquiesced in Justice Clark's opinion upholding a manslaughter conviction where the evidence that defendant was intoxicated at the time of an automobile accident was blood taken from him while he was unconscious. ${ }^{108}$ The Chief Justice spoke for himself, Black and Douglas in dissent. ${ }^{109}$

Frankfurter's difficulties in this shadowland between search and seizure and self incrimination ${ }^{110}$ may be contrasted with his precision in dealing with other issues of procedural due process : his eloquent protest against Oregon's placing on an alleged murderer the burden of proving insanity beyond a reasonable doubt ; ${ }^{111}$ his lone dissent from Black's view that a defendant seeking a gubernatorial stay of execution was not entitled to be represented at a medical

until the introduction of the evidence at trial, Gouled v. United States, 255 U.S. 298, 305 (1921), or where a pre-trial motion to suppress had been erroneously overruled. Id. at 312-3; Amos v. United States, 255 U.S. 313 (1921). Conceptually the doctrine of exclusion rests on the theory that the use at trial of evidence obtained in violation of the Fourth Amendment violates the Fifth Amendment's privilege against self-incrimination. See Boyd v. United States, supra at 630-5." Judged in this light, the crucial problem may be whether the privilege against self incrimination has been assimilated into the Fourteenth Amendment's due process clause, and Adamson itself shows that it has not been.

106. Rochin v. California, 342 U.S. 165 (1952).

107. Irvine v. California, 347 U.S. 128, 142 (1954). Compare Frankfurter's views in On Lee v. United States, 343 U.S. 747, 758 (1952) (dissenting opinion); Schwartz v. Texas, 344 U.S. 199, 204 (1952) (concurring opinion). See also Frankfurter's dissent, in which Douglas joined, in Rathbun v. United States, 26 U.S.L. WeEr 4042, 4044 (U.S. Dec. 9, 1957) ; cf. Benanti v. United States, 26 U.S.L. WeEk 4045 (U.S. Dec. 9, 1957).

108. Breithaupt v. Abram, 352 U.S. 432 (1957). Justice Clark, in the Irvine case, noted that had he been sitting at the time $W$ olf was decided he "would have applied the doctrine of Weeks v. United States, 232 U.S. 383 (1914), to the states," 347 U.S. at 138-thereby compelling exclusion at state trials of illegally seized evidence; but Justice Clark provided the fifth vote for affirmance in Irvine because "Wolf remains the law and, as such, is entitled to the respect of this Court's membership." Ibid.

109. 352 U.S. at 440 . Douglas and Black also dissented separately. Id. at 442 . The Court may shortly have occasion to consider the problem in a federal context. See Blackford v. United States, 247 F.2d 745 (9th Cir. 1957). Heroin, packaged in a condom, was removed from defendant's rectum. "There is nothing in the Bill of Rights which makes body cavities a legally protected sanctuary for carrying narcotics." Id. at 753. Judge Stephens dissented. Id. at 754 .

110. For like difficulties, compare Rea v. United States, 350 U.S. 214 (1956), in which Frankfurter joined, with Stefanelli v. Minard, 342 U.S. 117 (1951). See, generally, Handler, The Fourth Amendment, Federalism and Mr. Justice Frankfurter, 8 SYRAcuse L. REv. 166 (1957).

111. Leland v. Oregon, 343 U.S. 790, 802 (1952) (dissenting opinion). Black joined Frankfurter in dissent. 
inquiry into his claim of insanity $;^{112}$ his sense of horror at the possibility that Pennsylvania might execute a man declared sane by a psychiatrist himself thereafter adjudged insane. ${ }^{113}$

These cases illustrate two of Frankfurter's grave concerns about the administration of American criminal law: capital punishment, ${ }^{114}$ and the nexus between crime and mental illness. 115 They also illustrate what is fundamental to Frankfurter's approach to due process of law-that it is a process ${ }^{110}$ and not the largely static formula urged by the Adamson dissenters. The "process of judicial inclusion and exclusion"117 to which Frankfurter so often adverts is a process he has himself been part of, in a long and useful career. $\mathrm{He}$ saw the views of Tom Mooney's case he helped to formulate nearly forty years ago ratified by the Supreme Court as a denial of due process nearly two decades later. ${ }^{118}$ Thirty years ago, his memorable attack on the insubstantiality of the case against Sacco and Vanzetti ${ }^{119}$ went for naught when honorable judges, including Holmes, were unable to equate the trial judge's prejudice with a denial of due process. ${ }^{120}$ But today such a case would likely fall within the expanded ambit of those words. ${ }^{121}$

112. Solesbee v. Balkcom, 339 U.S. 9, 14 (1950). Douglas did not participate.

113. Smith v. Baldi, 344 U.S. 561, 570 (1953) (dissenting opinion). Black and Douglas joined Frankfurter in dissent.

114. See Frankfurter, The Problem of Capital Punishment, in OF Law and MEN 77 (1956). Frankfurter's due process clause is avowedly stricter in capital cases, even where the death sentence is not in fact imposed. See, e.g., his concurrence in Reid $v$. Covert, 354 U.S. 1, 41 (1957), recognizing a Fifth Amendment right to trial before a civilian court rather than a court-martial for dependents of servicemen abroad, at least in capital cases; $c f$. the right to counsel problem discussed in text at note 95 supra.

115. Compare Fisher v. United States, 328 U.S. 463, 477 (1946) (dissenting opinion). See Frankfurter, The Problem of Capital Punishment, in Of Law and Men 77, 82-97 (1956).

116. Joint Anti-Fascist Refugee Comm. v. McGrath, 341 U.S. 123, 162-63 (1951).

117. Davidson v. New Orleans, 96 U.S. 97, 104 (1878).

118. As Secretary and Counsel of the Federal Mediation Commission, which inquired into the Mooney case, Frankfurter joined in reporting to President Wilson that "the feeling of disquietude aroused by the case must be heeded, for if unchecked, it impairs the faith that our democracy protects the lowliest and even the unworthy, against false accusations." Symes, Our American Dreyrus Case 19 (1935). In 1935, the Court, in Mooney v. Holohan, 294 U.S. 103, although remitting petitioner to the appropriate state remedy, declared that the alleged misconduct of the prosecuting officials-in particular their knowing use of perjured evidence-constituted a denial of due process.

119. Frankfurter, The Case of Sacco and Vanzetti, 139 Atr.ANTIC Montmly 409 (1927). The enormous impact of Frankfurter's masterful analysis of the case is suggested by the comment of Chief Justice Taft in a letter written after the execution of Sacco and Vanzetti: "It is remarkable how Frankfürter [sic] with his article was able to present so large a body of readers a perverted view of the facts and then through the world-wide conspiracy of communism spread it to many, many countries." Jougrin \& MoRGAN, The Legacy of Sacco and Vanzetti 308 (1948).

120. Habeas corpus was denied by Holmes, and then, in turn, by Circuit Judge Anderson and District Judge Morton. 5 The SAcco-VAnzerm Case 5532-34 (1928). According to Holmes: "I cannot think that prejudice on the part of the presiding judge however strong would deprive the Court of jurisdiction, that is of legal power to decide the case, and in my opinion nothing short of a want of legal power to decide the case 
Determining case by case and year by year the unfolding content of the Fourteenth Amendment may well be a difficult task. But the process is not -or at least need not be-the expression of personal whim or the articulation of a body of "natural law."122 It is an aspect of a creative task the perspectives of which Marshall charted for the Court long ago-"we must never forget that it is a constitution we are expounding." 123 So considered, the endless process of adumbrating fundamental limitations on the power of government is part of the customary growth of the law:

"Little is the positive contribution that any one of us can hope to make, the impetus that any one of us can give, to the movement forward through the ages. That little will call for the straining of every faculty, the bending of every energy, the appeal to every available resource, within us or without. . . . We shall see that our little parish has its vistas that lie open to the infinite. We shall know that the process of judging is a phase of a never ending movement, and that something more is exacted of those who play their part in it than imitative reproduction, the lifeless repetition of a mechanical routine."124

To act on a narrower view of the judicial process is to escape from judgment.

authorizes me to interfere in this summary way with the proceedings of the State Court." Id. at 5532. A few days later, in a better-known opinion addressed to a somewhat different issue, Holmes denied a stay of execution pending the filing of a certiorari petition to review an unsuccessful attack in the Massachusetts courts. Id. at 5516-17. Justice Stone also denied a stay. Id. at 5517 .

121. Compare United States ex rel. Darcy v. Handy, 351 U.S. 454 (1956). Dissenting from the Court's acquiescence in the judicial conduct there attacked, Harlan, with Frankfurter and Douglas, said: "We should be especially scrupulous in seeing to it that the right to a fair trial has not been jeopardized by the conduct of a member of the judiciary." Id. at 469 .

122. See, e.g., Black in Adamson v. California, 332 U.S. 46, 68 (1947) (dissenting opinion). Frankfurter has on occasion candidly admitted the difficulty of determining when due process is offended. Speaking of Louisiana ex rel. Francis v. Resweber, 329 U.S. 459 (1947), in which Louisiana proposed to electrocute for the second time a defendant not killed the first time, he said: "I was very much bothered by the problem, it offended my personal sense of decency to do this. Something inside me was very unhappy, but I did not see that it violated due process of law." FRANKFURTER, The Problem of Capital Punishment, in OF LAW AND MEN 77, 98 (1956).

123. McCulloch v. Maryland, 17 U.S. (4 Wheat.) 316, 407 (1819). Frankfurter regards this as "the single most important utterance in the literature of constitutional lawmost important because most comprehensive and comprehending." Frankfurter, John Marshall and the Judicial Function, $69 \mathrm{HARv}$. L. REv. 217, 219 (1955), reprinted in FRANKFURTER, OF LAW AND MEN 3, 5 (1956).

124. Cardozo, The Growty of ine Law 141-43 (1924). This is of course the antithesis of the imitative process which Frankfurter, following Erie R.R. v. Tompkins, 304 U.S. 64 (1938), would have federal courts pursue in the disfavored area of diversity litigation. See note 77 supra; cf. Clark, State Law in the Federal Courts: The Brooding Omipresence of Erie v. Tompkins, 55 Y ALE L.J. 267, 290-96 (1946). But there are also diverse fashions in judicial imitation. Compare the views of Douglas, speaking for the Court, with those of Frankfurter, concurring on how a federal court should find state law, in Bernhardt v. Polygraphic Co., 350 U.S. 198, 205 (1956). 


\section{THE YALE LAW JOURNAL}

ROBERT T. BASSECHES JEROME H. RETCHMAN

Comment Editors

ROBERT L. BARD

Thomas D. Barr

William C. Baskin, JR.

Frederick I. BerNstein

David P. Bicks

Norman A. Bikales

Benjanirn W. Boley

Richard A. BRAdy

Newton D. BrenNer

David Burres

Peter D. Caldwell

Laura M. Chapman

Sydney M. Cone, III

Paul H. DeCoster

Robert J. Del Tufo

Robert J. ENGelMaN

MITCHel J. EzER
STEPHEN N. SHULMAN

Editor-in-Chief

\author{
Milton P. DeVane \\ Article and Book \\ Review Editor
}

W. L. F. FELSTINER Managing Editor

Arthur Fleischer, JR. SeTH E. Frank

Thomas N. FroHock

David Goldberg

BURT W. GRIFFIN

Milton S. Gwirtzman

NeIL S. HeCHT

Reuben L. Hedlund

ALAN M. Hofrman

JEROLD H. ISRAEL

STEPHEN J. JEIIN

N. Herscher Koblenz

IRVING I. LESNICK

Marcia R. Lockwood

JoHN C. MCGuire

Richard M. Meyer

Hugh G. MoultoN

Michael J. Nassau

Walter W. OberRett

Richard W. Pendeton, JR.

Chardes J. Prentiss

BURTON RAFFEL

Richard SEXToN

Douglas O. Smite, JR.

LEWIS A. STERN

Colin C. TAit

JoSEPH N. TAuUber

StanLEy E. Tobin

JOHN W. VANDOREN

Patricia W. Weinberg

T. CECIL Wray, JR.

JoHN K. MCNuLTY

AlaN L. Wurtzel

Marie McMahon

Business Secretary

\section{CONTRIBUTORS TO THIS ISSUE}

The Right Honourable Sir Owen Dixon. G.C.M.G., Chief Justice of the High Court of Australia.

Philip B. Kurland. Professor of Law, University of Chicago Law School.

Ernest J. Brown. Professor of Law, Harvard Law School.

Nathaniez L. Nathanson. Professor of Law, Northwestern University.

Clype W. Summers. Professor of Law, Yale Law School.

Lours F. Pollak. Associate Professor of Law, Yale Law School. 